\title{
TEKNOLOGI INFORMASI DESA, UPAYA MENINGKATKAN PARTISIPASI DAN KETERAMPILAN MASYARAKAT DALAM PEMBANGUNAN DESA (PEMANFAATAN LIMBAH MINYAK JELANTAH MENJADI KARBOL)
}

\author{
Fadilla Oktaviana $^{1}$, Ida Nuraida ${ }^{2}$ \\ ${ }^{1,2}$ Universitas Banten Jaya, Jl Syech Nawawi Albantani Serang, Banten, Indonesia \\ E-mail: fadillaoktaviana@unbaja.ac.id
}

\begin{abstract}
The aim of the Community Service Program, Kuliah Kerja Nyata-Pembelajaran dan Pemberdayaan Kepada Masyarakat (KKN-PPM) is to improve the skills of society, especially housewives. The partners of this activity are non-productive communities in Sindanglaya village, Cinangka. The problem faced does not know the use of used cooking oil/minyak jelantah to produce products that are useful and have selling value. The method of implementing this service is through (1) Survey through observation, interviews, and analysis of problems and potential of the village, (2) Training on making carbolic acid from minyak jelantah, (3) training on making detergent powder. The results of this program are increasing knowledge and skills of the community regarding (1) processing minyak jelantah into carbolic acid, and (2) making powder detergent. This program is expected to facilitate the community in increasing their knowledge and skills in processing used/waste materials into products that are useful and have selling value, therefore that the societies in Sindanglaya become productive communities.
\end{abstract}

Keywords: Community Learning and Empowerment, Waste Management, Used Cooking Oil

\begin{abstract}
ABSTRAK
Tujuan Program Pengabdian Masyarakat Kuliah Kerja Nyata-Pembelajaran dan Pemberdayaan Kepada Masyarakat (KKN-PPM) adalah untuk meningkatkan keterampilan masyarakat Desa khususnya Ibu rumah tangga. Mitra dari kegiatan ini adalah masyarakat non produktif di desa Sindanglaya, Kec. Cinangka. Permasalahan yang dihadapi yaitu belum mengetahui pemanfaatan minyak jelantah untuk mengahasilkan produk yang berguna dan memiliki nilai jual. Metode pelaksanaan pengabdian ini yaitu melalui (1) Survey melalui pengamatan, wawancara, dan analisis permasalahan dan potensi desa, (2) Pelatihan pembuatan karbol dari minyak jelantah, (3) pelatihan pembuatan detergen bubuk. Hasil dari program ini adalah bertambahnya pengetahuan dan keterampilan masyarakat mengenai (1) pengolahan limbah minyak jelantah menjadi karbol, dan (2) membuat detergen bubuk. Program ini diharapkan dapat memfasilitasi masyarakat dalam meningkatkan pengetahuan dan keterampilan dalam mengolah bahan bekas menjadi produk yang berguna dan memiliki nilai jual, sehingga masyarakat desa sindanglaya menjadi masyarakat yang produktif.
\end{abstract}

Kata Kunci: Pembelajaran dan Pemberdayaan Masyarakat, Pengolahan Limbah, Minyak jelantah

\section{PENDAHULUAN}

Pada zaman dahulu, sekitar Tahun 1928 keberadaan Desa Sindang Laya sudah dikenal sebagai bagian dari wilayah kecamatan Cinangka, kewedanaan Anyar Kabupaten serang, merupakan Desa Induk yang mengandung arti bahwa "Sindang berarti Singgah atau Mampir, sedangkan Laya mempunyai arti Layon/betah/kerasan, yang berkesimpulan bahwa, setiap orang 
yang mampir/singggah di wilayah ini maka akan merasa betah sampai akhir hayatnya". Hal itu terbukti sampai sekarang bahwa warga masyarakat Desa Sindanglaya terdiri dari masyarakat sekitar dan saat ini sudah berbagai suku yang berasal dari berbagai daerah Indonesia yang (Majemuk), oleh karena itu tugas kedinasan, perniagaan adalah sector penting.

Sebagian besar penduduk sekitar bekerja disektor perkebunan,pertanian,memanfaat lahan kosong,namun, Pada pertengahan Tahun 2000 Desa Sindang laya dikenal sebagai daerah pesisir dan fanorama pantai yang indah,sehingga penduduk sekitar beralih propesi yang mata pencaharian sebagian besar pedagang warung pantai,dan pantai banyak pengunjung wisatawan asing, sehingga dapat meningkatkan perekonomian warga Desa Sindanglaya. Peningkatan ekonomi terlihat pesat setelah di bukanya Pantai Pasir Putih Plorida Indah yang terletak disebelah barat Kantor Desa Sindanglaya, dimana para pedagang diprioritaskan untuk warga Desa Sindanglaya. Bukan hanya pantai saja Desa Sindanglaya sebagian penduduk tinggal di daerah pegunungan yang masih asri, dan mempunyai beberapa mata air/sumber yang digunakan penduduk sebagai air minum yang sehat,dan banyak pengunjung wisata local yang ingin mendaki gunung tersebut dan melihat pemandangan yang indah dipuncak gunung tersebut.

Minyak sayur atau minyak makan menjadi salah satu bahan yang banyak digunakan oleh masyarakat di desa Sindang laya. Hal ini mengingat banyaknya pedagang makanan di sekitar pantai dan juga aktivitas rumah tangga yang menggunakan minyak sayur tersebut. Dari hasil survey yang dilakukan melalui pengamatan dan wawancara, belum adanya pengetahuan dan keterampilan masyarakat mengenai pengolahan limbah minyak jelantah. Yang dilakukan oleh masyarakat hanya membuang yang dapat merusak lingkungan atau menggunakannya kembali yang dapat menggangu kesehatan dan menyebabkan penyakit seperti kolesterol dan yang lainnya. Oleh karena itu, dalam kegiatan KKN-PPM bertujuan untuk meningkatkan pengetahuan dan keterampilan masyarakat desa khususnya Ibu rumah tangga di desa Sindanglaya, Kec. Cinangka dalam pengolahan limbah minyak jelantah untuk menghasilkan produk yang berguna dan memiliki nilai jual.

\section{METODE}

Metode yang digunakan selama proses pelatihan diantaranya adalah (1) pembekalan kepada mahasiswa pendamping lapangan yang dilaksanakan di universitas Banten Jaya dengan pemateri Bapak Syarif Hidayat, ST., M.Eng dari PT. Pentaza Multikarya yang menjadi salah satu mitra pada kegiatan KKN-PPM ini, (2) pelaksanaan pelatihan pada masyarakat di desa Sindanglaya yang diawali dengan pemberian materi mengenai bahaya limbah minyak jelantah dan cara pemanfaatannya, pengenalan nama-nama bahan kimia yang digunakan, (3) Demonstrasi pembuatan karbol dan detergen bubuk yang diperagakan oleh mahasiswa pendamping, (4) 
Praktek Pembuatan karbol dan detergen bubuk dengan bimbingan Tim KKN-PPM dan mahasiswa pendamping.

1. Alat, Bahan dan diagram alur pembuatan karbol dari minyak jelantah

Kegunaan-keguanaan kreolin atau karbol di antaranya adalah sebagai pembersih lantai sekaligus pembunuh kuman, bakteri maupun jamur, mengatasi bau yang sangat membandel, karbol yang ditambahkan deterjen bisa digunakan untuk membersihkan kerak- kerak yang membandel. Pada dasar nya karbol terbuat dari campuran Arpus, NaOH, Camper, Pine Oil/Minyak pinus dan Air.padapelatihan ini minyak pinus yang digunakan dalam bahan dasar pembuatan karbol digantikan dengan minyak jelatah sesuai dengan tujuan penelitian untuk memanfaatkan minyak jelantah. Dibawah ini adalah penjelasan mengenai alat, bahan dan diagram alur pembuatan karbol dari minyak jelantah.

a. Alat

Alat yang digunakan adalah gelas beaker, batang pengaduk, mortar, ayakan, cawan petri, kertas saring, erlenmeyer, gelas ukur, botol plastik dan timbangan analitik.

b. Bahan

Bahan yang digunakan adalah minyak jelantah, arpus, $\mathrm{NaOH} 30 \%$, naftalena, air dan pewarna sintesis.

c. Cara Kerja

1) Persiapan bahan

Minyak jelantah disaring menggunakan kertas saring kemudian diukur sebanyak $10 \mathrm{ml}$. Selain itu, arpus dan naftalen yang akan digunakan dihaluskanterlebihdahulu menggunakan mortar. Arpus yang telah dihaluskan kemudian diayak agar didapat arpus yang benar-benar halus.

2) Pembuatan karbol

Sebanyak $20 \mathrm{ml} \mathrm{NaOH} \mathrm{30 \%} \mathrm{dilarutkan} \mathrm{ke} \mathrm{dalam} 1 \mathrm{~L}$ air kemudian ditambahkan $50 \mathrm{~g}$ arpus secara perlahan-lahan sambil terus diaduk. Apabila masih terdapat endapan atau arpus yang tidak larut, ditambahkan kembali $\mathrm{NaOH}$ sedikit-sedikit sampai semua arpus larut.Larutan didiamkan selama \pm 15 menit. Sambil menunggu, larutkan $2.5 \mathrm{~g}$ naftalen dalam $10 \mathrm{ml}$ minyak jelantah yang telah disaring. Agar naftalen tersebut larut, panaskan campuran di atas penangas air.Setelah itu, campuran naftalen-minyak dituangkan ke dalam larutan arpus sambil diaduk.Karbol yang telah dibuat siap di kemas. 
d. Diagram alur proses pembuatan karbol dari minyak jelantah

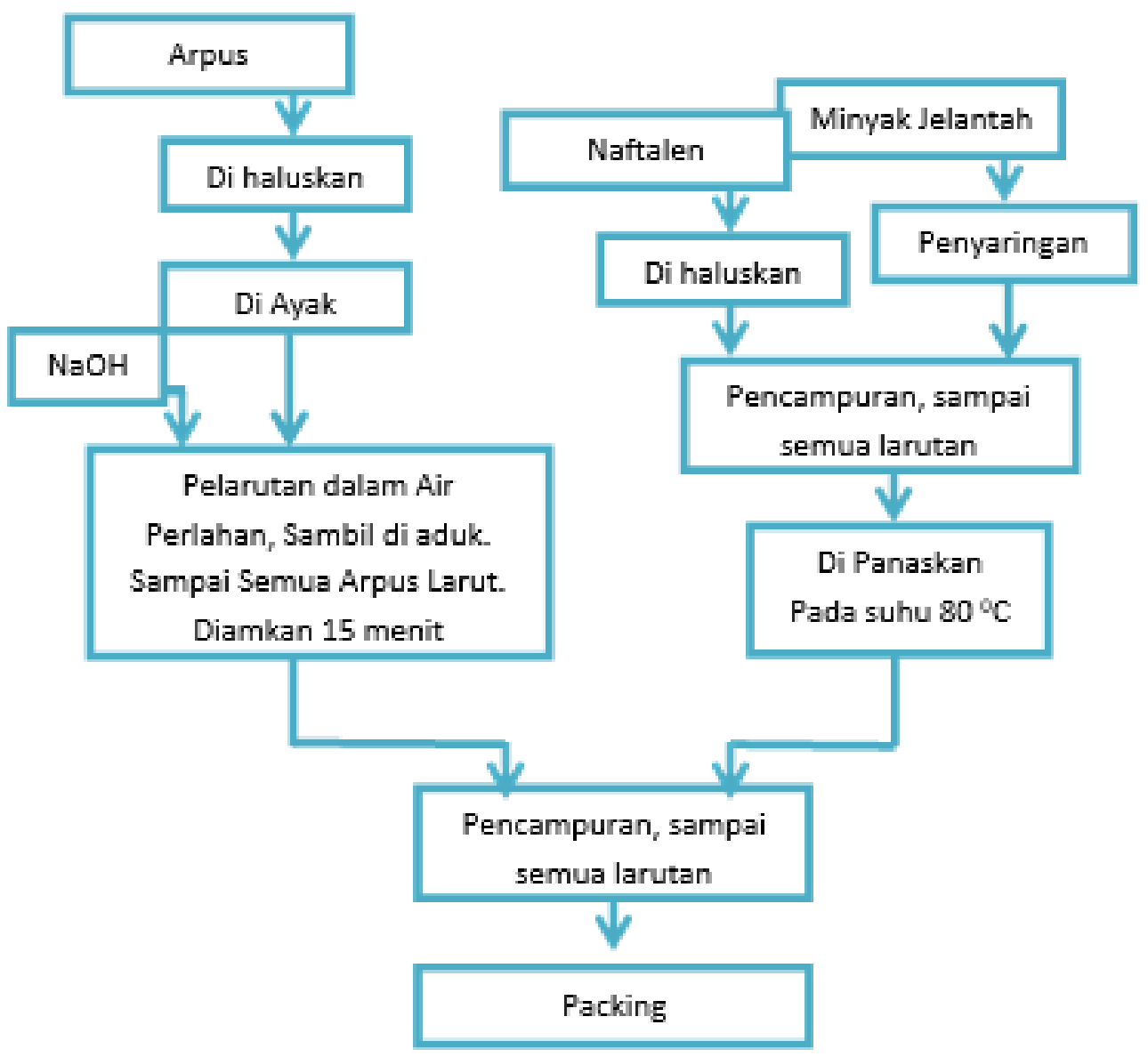

\section{Diagram 1. Alur Proses Pembuatan Karbol dari Minyak Jelantah}

2. Alat, Bahan dan diagram alur pembuatan detergen bubuk

Dibawah ini adalah penjelasan mengenai alat, bahan dan diagram alur dalam pembuatan detergen bubuk:

a. Alat

Peralatan yang dibutuhkan dalam membuat detergen bubuk adalah baskom, pengaduk kayu, dan saringan deterjen.

b. Bahan Aktif

Bahan aktif ini merupakan bahan inti dari deterjen sehingga bahan ini harus ada dalam pembuatan deterjen.Secara fungsional bahan mempunyai andil dalam meningkatkan daya bersih. Bahan aktif dari sabun bubuk adalah garam Linear Alkyl Benzene Sulfonat (LAS).

c. Bahan pengisi

Bahan ini berfungsi sebagai bahan pengisi dari keseluruhan bahan baku. Pemberian bahan pengisi ini dimaksudkan untuk memperbesar atau memperbanyak volume. Keberadaan bahan 
ini dalam deterjen semata-mata dilihat dari aspek ekonomis. Bahan pengisi deterjen disini menggunakan Sodium Sulfat (Na2SO4).

d. Bahan penunjang

Salah satu contoh bahan penunjang deterjen adalah soda abu (Na2CO3) yang berbentuk serbuk putih. Bahan penunjang ini berfungsi sebagai meningkatkan daya bersih. Keberadaan bahan ini dalam deterjen tidak boleh terlalu banyak, sebab dapat menimbulkan efek panas pada tangan saat mencuci pakaian. Bahan penunjang yang digunakan adalah STPP (sodium tripolyposphate) yang juga penyubur tanaman.

e. Bahan Tambahan (aditif)

Bahan tambahan ini sebenarnya tidak harus ada didalam pembuatan deterjen. Namun demikian, produsen mencari hal-hal baru untuk mengangkat nilai dari deterjen itu sendiri. Salah satu contoh bahan tambahan ini adalah Enzym AR. Bahan ini berbentuk serbuk putih yang berfungsi mencegah kotoran kembali kepakaian (anti redeposisi).

f. Bahan Pewangi/ Bibit Parfum

Keberadaan bahan wangi ini sangat penting keberadaannya, sebab suatu deterjen dengan kualitas baik, Harum\&Disukai Pelanggan. Parfum untuk deterjen bentuknya cair kekuningkuningan. Pemilihan parfum ini sangat penting, karena biasanya konsumen selalu membau dulu barang yang akan dibeli, baru mencoba untuk memakai produk tersebut.

g. Bahan Tambahan untuk membuat sabun yang kualitas istimewa

Extrableach : Untuk Memutihkan Cucian yang khusus berwarna putih, pemakaiannya 3-10\% Lipozyme : Pembersih noda yang disebabkan oleh minyak, lemak \& gemuk.

Dengan ditambah lypozyme, maka daya cuci sabun terhadap kotoran yang mengandung minyak, lemak ataupun gemuk yang membandel akan lebih mudah dibersihkan. Dosis pemakaian 2-10\%.

Protease : Pembersih noda yang membandel disebabkan oleh protein, seperti darah, kecap, susu, saos dll.

h. Komposisi Pembuatan Deterjen

1) LAS $5-10 \%$

2) Cottoclarin $5-10 \%$

3) $\mathrm{Na} 2 \mathrm{SO} 410-20 \%$

4) $\mathrm{Na} 2 \mathrm{CO} 335 \%-50 \%$

5) STPP $5-20 \%$

6) Enzym AR 2-10\%

7) Parfum secukupnya 
i. Diagram alur proses pembuatan detergen

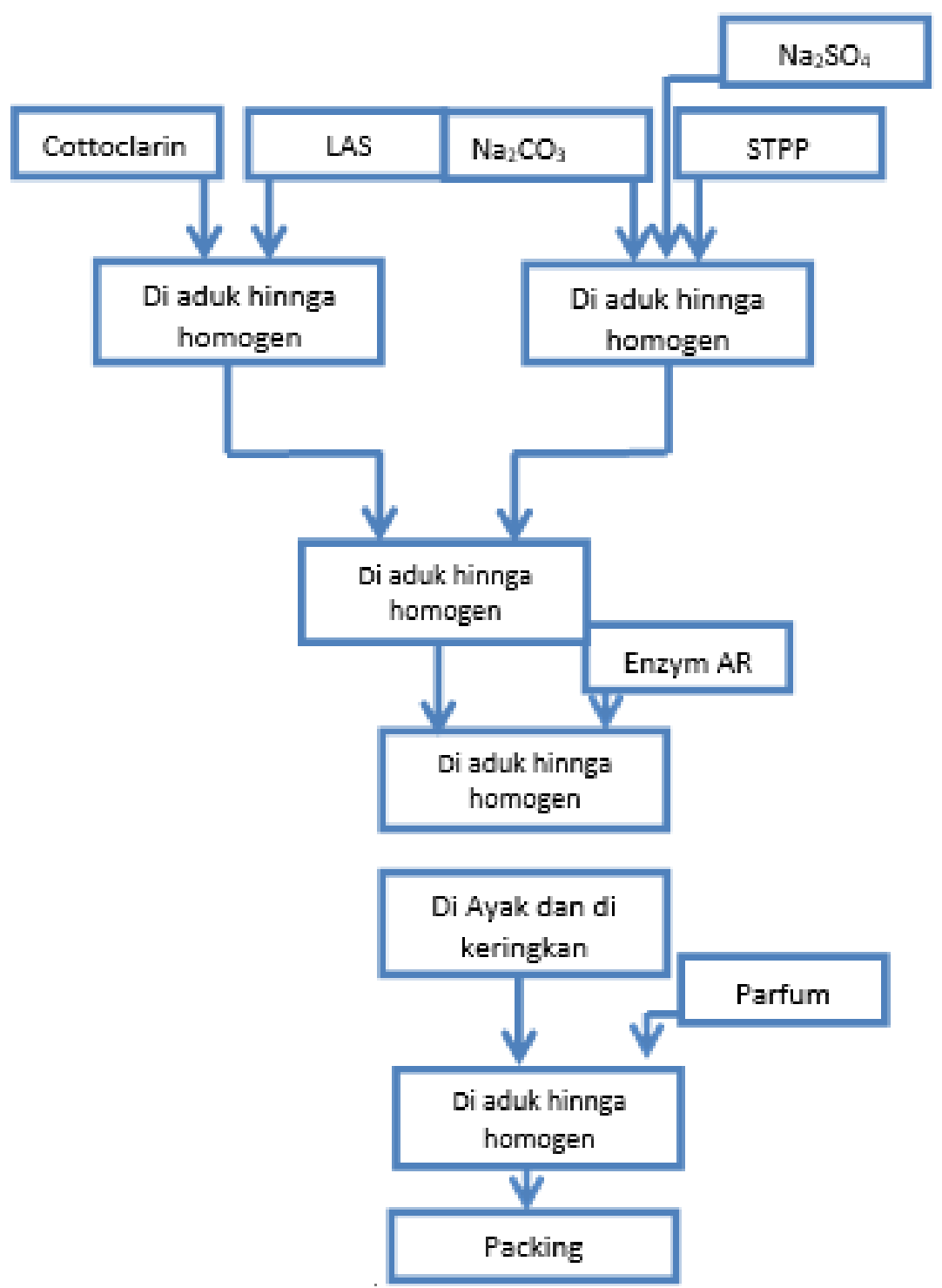

Diagram 2. Alur Proses Pembuatan Detergen

\section{HASIL DAN PEMBAHASAN}

1. Pembekalan kepada mahasiswa pendamping lapangan

Kegiatan yang pertama kali dilakukan adalah pembekalan kepada mahasiswa pendamping lapangan mengenai materi pelatihan yang akan dilaksanakan di desa Sindanglaya, dalam hal ini materi yang disampaikan mengenai pengolahan limbah minyak jelantah menjadi karbol dan pembuatan detergen bubuk. 

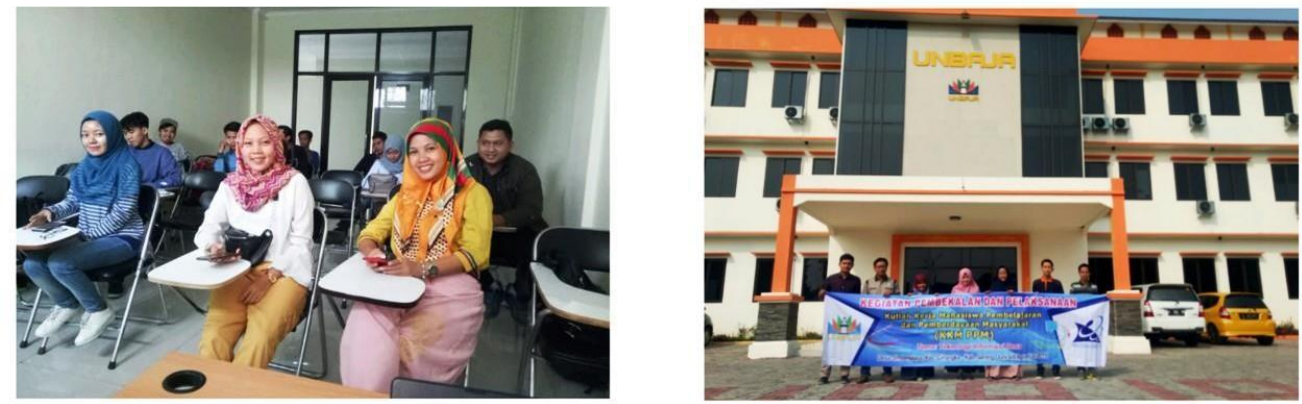

Gambar 1. Kegiatan Pembekalan Mahasiswa Pendamping

Kegiatan ini dilaksanakan di Universitas Banten Jaya, Kampus 2 yang beralamat di Jln. Syeikh Nawawi Al Bantani, Curug, Kota Serang pada hari Jum'at, 28 Juni 2019 dengan pemateri Bapak Syarif Hidayat, ST., M.Eng sebagai perwakilan dari mitra KKN-PPM yaitu PT. Pentaza Multikarya. Kegiatan pembekalan ini berisi dua sesi yaitu sesi pertama penyampaian materi dan sesi kedua praktek. Kegiatan ini dibuka langsung oleh ketua LP3M Universitas Banten Jaya, Nur Hidayanti, M.Pd.

2. Pelaksanaan pelatihan; pemberian materi mengenai bahaya limbah minyak jelantah dan cara pemanfaatannya, pengenalan nama-nama bahan kimia yang digunakan.

Kegiatan selanjutnya yaitu pelaksanaan KKN-PPM di Desa Sindanglaya dengan tema "Teknologi Informasi Desa, Upaya Meningkatkan Partisipasi dan Keterampilan Masyarakat dalam Pembangunan Desa (Pemanfaatan Limbah Minyak Jelantah menjadi Karbol dan Detergen di Desa Sindanglaya, Kec. Cinangka)”. Kegiatan dilaksanakan pada hari sabtu, 29 Juni 2019.
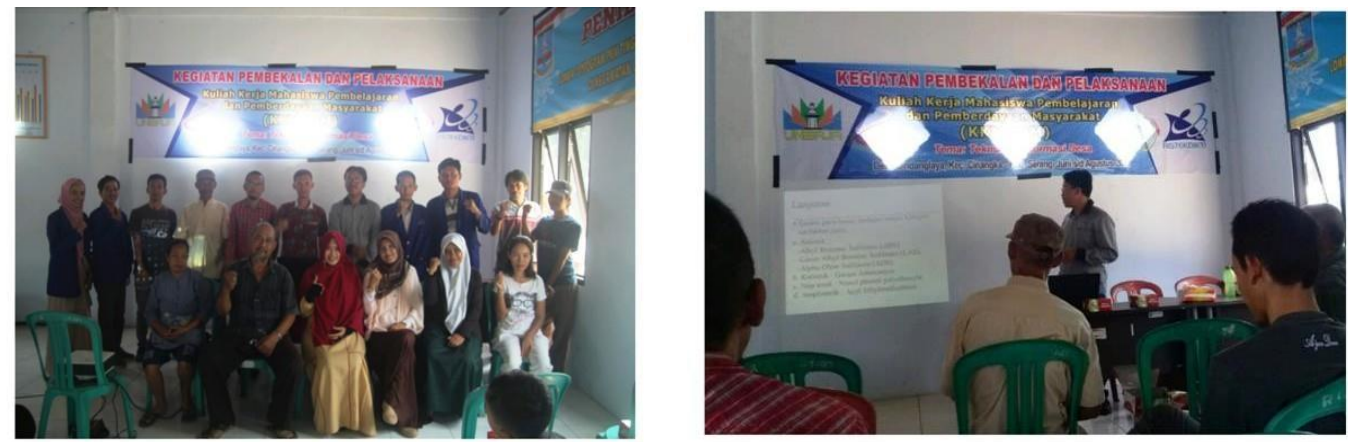

Gambar 2. Kegiatan KKN-PPM di Desa Sindanglaya

Kegiatan ini dilaksanakan di kantor desa Sindanglaya yang dihadiri oleh sejumlah perangkat desa dan masyarakat desa dalam hal ini dikhususkan kepada ibu rumah tangga sebagai pesertanya. Ibu Hj. Kartini Edi sebagai perangkat, sebagai perwakilan dari kepala Desa Sindanglaya, Kec. 
Cinangka membuka kegiatan KKN-PPM ini. Kemudian dilanjutkan dengan penyampain materi mengenai pengolahan limbah minyak jelantah menjadi karbol dan pembuatan detergen bubuk yan disampaikan oleh Bapak Syarif Hidayat, ST., M.Eng sebagai perwakilan dari mitra KKN-PPM yaitu PT. Pentaza Multikarya. Antusiasme terlihat tidak hanya ibu rumah tangga yang menjadi peserta pada pelatihan ini, tetapi juga bapak- bapak baik masyarakat maupun perankat desa yang menjadi peserrta juga pada kegiatan pelatihan ini. Hal ini terlihat pada sesi diskusi yaitu banyaknya pertanyaan yang disampaikan mengenai materi yang disampaikan.

3. Demonstrasi pembuatan karbol dan detergen bubuk yang diperagakan oleh mahasiswa pendamping

Kegiatan ketiga yaitu demontrasi pembuatan karbol dari minyak jelantah dan pembuatan detergen bubuk. Demontrasi ini dilaksanakan oleh mahasiswa pendamping serta tim dosen KKNPPM. Kegiatan ini diselingi tanya jawab dari masyarakat, terlebih mengenai bahan-bahan kimia, baik dari nama, ukuran, harga, serta informasi toko kimia terdekat yang bisa dikunjungi.

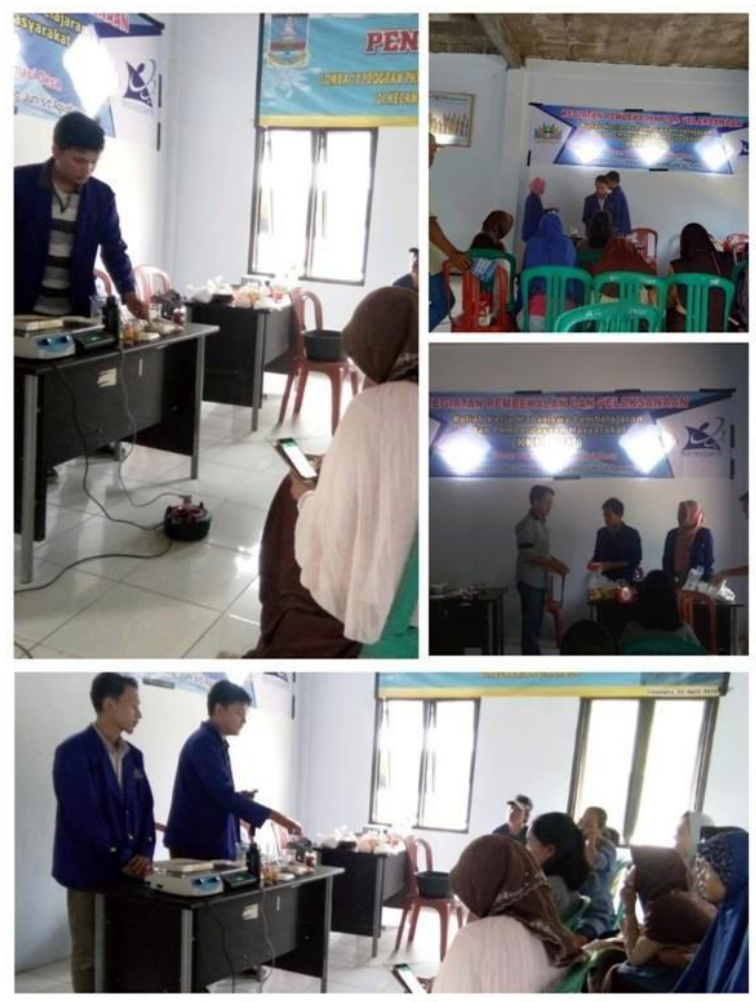

\section{Gambar 3. Demonstrasi Pembuatan Karbol dari Minyak Jelantah dan Detergen Bubuk}

Demonstrasi ini dilakukan oleh mahasiswa yang sudah diberikan pelatihan terlebih dahulu pada kegiatan pembekalan. Sehingga pada saat kegiatan pelaksanaan KKN-PPM, mahasiswa bisa menjadi tutor dan juga pendamping bagi masyarakat. Mahasiswa yang terlibat pada kegiatan KKN-PPM ini terdiri dari lintas fakultasn dan program studi yang telah mengontrak Mata Kuliah KKM di UNBAJA. 
4. Praktek Pembuatan karbol dan detergen bubuk dengan bimbingan Tim KKN-PPM dan mahasiswa pendamping

Kegiatan selanjutnya yaitu pelatihan dan pendampingan masyarakat dalam membuat karbol dan detergen bubuk yang dilaksanakan di kantor desa Sindanglaya, Kec. Cinangka. Kegiatan ini dilakukan sampai karbol dan detergen bubuk dapat dihasilkan. Hasil dari pelatihannya kemudian menjadi buah tangan bagi masyarakat yang telah mengikuti. Harapannya masyarakat tersebut dapat menjadi duta di desanya untuk bisa mempraktekkan bagaimana cara memanfaatkan minyak jelantah menjadi karbol dan membuat detergen bubuk. Kedua barang ini sangat sering digunakan untuk kebutuhan rumah tangga.
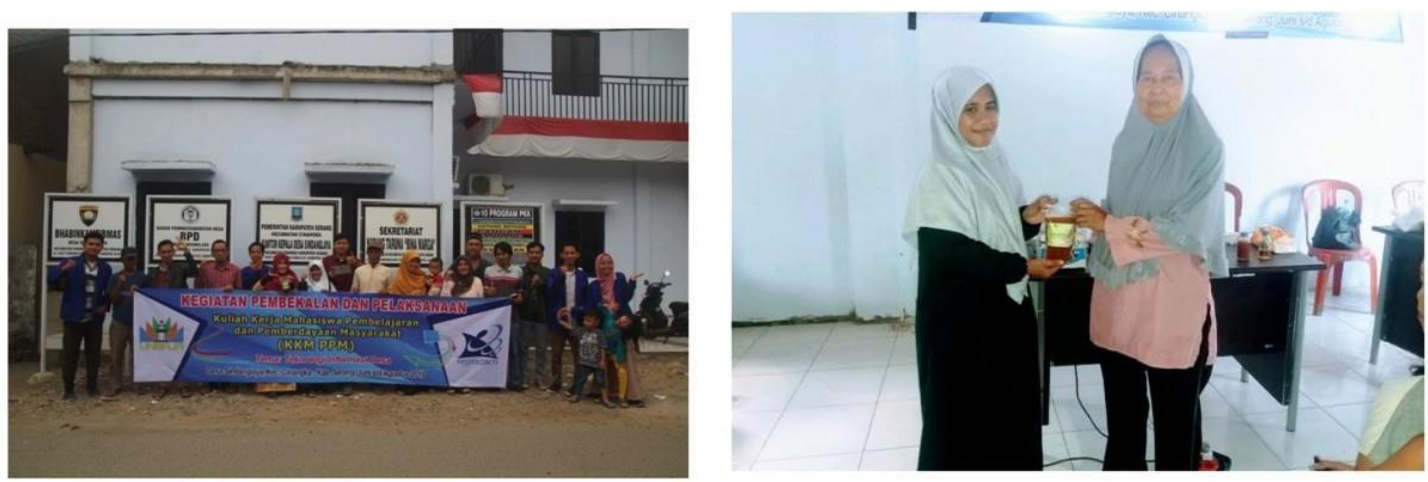

\section{Gambar 4. Pelatihan Pembuatan Karbol dari Minyak Jelantah dan Detergen Bubuk}

Tidak hanya pelatihan pembuatan karbol dari minyak jelantah dan detergen bubuk, tetapi juga diberi pemaparan mengenai pengemasan yang menarik, sederhana dan mudah didapat. Pengemansan yang menarik dari sebbuah produk dapat meningkatkan daya jual dari produk itu sendiri. Seringkali, pengemasan menjadi permasalahan dari produk hasil kreatifitas masyarakat. Oleh karena itu, pengemasan produk menjadi salah satu materi dari pelatihan pada kegiatan KKNPPM 2019 ini.

\section{KESIMPULAN}

Setelah dilakukan kegiatan Kuliah Kerja Nyata-Pembelajaran dan Pemberdayaan Kepada Masyarakat (KKN-PPM) tahun 2019 dengan tema "Teknologi Informasi Desa, Upaya meningkatkan partisipasi dan keterampilan masyarakat dalam pembangunan desa (Pemanfaatan Limbah Minyak Jelantah menjadi Karbol dan Detergen)”, maka terjadi peningkatan pengetahuan dan keterampilan masyarakat tentang mengolah minyak jelantah menjadi karbol yang dapat digunakan untuk membersihkan lingkungan khususnya toilet, serta terjadi peningkatan pengetahuan dan keterampilan dalam membuat detergen bubuk dengan bahan kimia sederhana yang mudah diperoleh disekitar masyarakat. Dengan meningkatkan pengetahuan dan 
keterampilan dalam mengolah bahan bekas menjadi produk yang berguna dan memiliki nilai jual, harapannya masyarakat desa sindanglaya menjadi masyarakat yang produktif.

\section{UCAPAN TERIMAKASIH}

Ucapan terimakasih disampaikan kepada

1. Direktorat Riset dan Pengabdian Masyarakat, Direktorat Jenderal Penguatan Riset dan Pengembangan, Kementerian Riset, Teknologi, dan Pendidikan Tinggi yang telah memberikan kesempatan dan dukungan untuk melaksanakan kegiatan Kuliah Kerja Nyata-Pembelajaran dan Pemberdayaan Kepada Masyarakat (KKN-PPM) dengan tema "Teknologi Informasi Desa, Upaya meningkatkan partisipasi dan keterampilan masyarakat dalam pembangunan desa (Pemanfaatan Limbah Minyak Jelantah menjadi Karbol dan Detergen) tahun pelaksanaan 2019"

2. Kepala Desa Sindang Laya yang telah bekerjasama dan memberikan kesempatan untuk dapat melakukan pengabdian di desa tersebut.

3. Dosen Pembimbing dan Tim Karboling Universitas Banten Jaya yang telah bekerjasama dalam pelaksanaan kegiatan KKN-PPM sebagai tutor dalam pembuatan karbol dari minyak jelantah

\section{DAFTAR PUSTAKA}

Panduan Penelitian dan Pengabdian kepada masyarakat edisi XII, Direktorat Riset dan Pengabdian Masyarakat, Direktorat Jenderal Penguatan Riset dan Pengembangan, Kementerian Riset, Teknologi, dan Pendidikan Tinggi tahun 2018

Hariyadi, Priwiyatno, 2015. Minyak Goreng Bekas, Waroeng-e arek-arek mesin. ITS: Surabaya.

Nur, F.H. 2006. Teknologi Mengurangi Asam lemak trans. Food Review Indonesia. Vol.1 No.2. Bogor

Qolby, AL, Dkk, 2015. Pemanfaaatn Minyak Jelantah untuk Pembuatan Karbol.Digilib.uns.ac.id.

Cara membuat deterjen bubuk https://www.google.com/amp/s/blueskypharmacy. wordpress.com/2016/01/06/cara-membuat- deterjen-bubuk/amp/. Diakses tanggal 22 Mei 2019.

Desa Sindanglaya, Cinangka. https://id.m.wikipedia.org/wiki/Sindanglaya,Cinangka, _Serang. Diakses tanggal 22 mei 2019. 